THURSDAY, JULY i6, I9I4.

\section{LOCOMOTIVES AND RAILWAYS.}

The Railways of the World. By Ernest Protheroe. Pp. $\mathrm{xx}+75^{2}+\mathrm{xvi}$ plates. (London: George Routledge and Sons, Ltd., n.d.) Price $7 s .6 d$. net.

BOYS of to-day are indeed fortunate in their B literature; books are available on most subjects, written to interest them-not merely fairy tales, but dealing with many themes in a scientific way and in language free from technical terms likely to worry the young mind.

The volume under notice is certainly one of the best of its kind, "Every Boy's Book of Railways and Steamships" by the same author was most interesting, but "The Railways of the World" is alluring; and as most boys love a locomotive and study railway working, they will indeed be delighted with the contents of this book and hasten to possess a copy.

To commence with, the usual account of the early locomotive and railway is dealt with: and, of course, Stephenson is given the lion's share of the credit. It is a pity that the earlier pioneers are being overlooked and forgotten. For instance, the Liverpool and Manchester and many other railways were projected and surveyed by William James, called by many "The Father of Railways," before Stephenson appeared on the scene. Again, the famous locomotive "The Rocket" was fitted with a multitubular boiler, the very soul of a locomotive, by the Stephenson's--this boiler being of William H. James's design, and used by Messrs. Losh and Stephenson, as recorded in an agreement dated September I, r82 I.

In a volume of this nature it is possible to deal with much interesting matter. In chapter iii. we find the locomotive past and present well treated. Stroudley's "Gladstone" awakens many reminiscences and we are only too pleased to find on page 42I that the author considers that "William Stroudley proved himself one of the cyclopean knights of locomotive engineering who have left their mark on British railway practice." With this we can cordially agree. Stroudley was the first locomotive engineer to pay attention to the details of locomotive design and his master hand can even now be recognised on many British railways.

Reference is made to the famous Caledonian engine No. 123, which did such remarkable work in "the race to the North" in I888. This engine was built by Neilson and Co. of Glasgow, and not by the railway company as stated.

Chapter iv. is most interesting. Locomotives of to-day are described in a capable way, but as the space at our disposal is limited, detailed comment is impossible. We cannot, however, agree that "a built-up crank axle is screwed together," see page I02. The parts are heated and shrunk together, and sometimes have the additional security of a screwed plug in the joints.

It is interesting to note that our author refers to certain notable cases of heredity in locomotive engineering ; many are, of course, interesting, but if the subject were pursued to the bitter end perhaps the records would not be so conclusive.

On page $35^{8}$ the old fairy tale of building a sixcoupled goods engine and tender in ten working hours is served up, but nothing is said as regards its cost. The inconvenience of specially preparing and arranging the work at the expense of disorganising the whole works for the time being is not referred to. If there was any economy the practice would be common, but, as a matter of fact, this is not the case.

The chapters dealing with Scottish railways are far too short. The locomotive history of the Caledonian railway is one of intense interest. The late Mr. Dugald Drummond of the London and South Western Railway became famous there, and more recently the magnificent locomotives, designed by Mr. J. F. McIntosh, have been the delight of locomotive connoisseurs; "The Dunalastair" being the first of his creation, the first with "the big boiler," a practice carefully followed ever since. "The Highland Chief," a fine sample of North British practice, and an excellent example of the big boiler policy is illustratedfacing page 482 .

The volume concludes with interesting descriptions of Continental practice and that of other parts of the world, and the work has been well done. Nominally written for boys, the language used is sufficiently non-technical to be clear; on the other hand, the book will be found very interesting to the railwayman. The information is sound, the illustrations good, and the general appearance excellent.

N. J. L.

\section{PARASITIC PROTOZOA.}

Some Minute Animal Parasites, or Unseen Foes in the Animal World. By Drs. H. B. Fantham and Annie Porter. Pp. xi-3ig. (London: Methuen and Co., Ltd., I9r4.) Price $5 s$. net.

THIS volume gives an account of the principal 1 Protozoa which produce disease in man and in animals associated with man, e.g. domestic animals, game, bees, etc. As the book is intended to be of service to different classes of readers it has been written in a semi-popular NO. 2333, VOL. 93] 